\title{
The human small intestine comprises two subsets of regulatory Foxp3+ CD4 T cells with very different life span and functional properties
}

Sudhir Kumar Chauhan ${ }^{1,2}$, Raquel Bartolomé Casado ${ }^{1}$, Ole J.B. Landsverk ${ }^{1}$, Jørgen Jahnsen ${ }^{3}$, Rune Horneland ${ }^{4}$, Sheraz Yaqub ${ }^{5}$, Einar Martin Aandahl ${ }^{2,4}$, Knut E.A. Lundin ${ }^{6}$, Espen S. Bækkevold $^{1}$, Frode L. Jahnsen ${ }^{1}$

${ }^{1}$ Department of Pathology, Oslo University Hospital and University of Oslo, Oslo, Norway.

${ }^{2}$ Department of Cancer Immunology, Institute for Cancer Research, Oslo University Hospital, Oslo, Norway

${ }^{3}$ Department of Gastroenterology, Akershus University Hospital, Lørenskog, Norway

${ }^{4}$ Department of Transplantation Medicine, Section for Transplant Surgery, Oslo University Hospital, Rikshospitalet, Oslo, Norway.

${ }^{5}$ Department of Gastrointestinal Surgery, Oslo University Hospital, Rikshospitalet, Oslo, Norway

${ }^{6}$ Department of Gastroenterology, Oslo University Hospital, Rikshospitalet, Oslo, Norway

\section{ABSTRACT}

Gut resident regulatory $\mathrm{CD} 4+\mathrm{T}$ (Tregs) cells in mice are mainly specific for intestinal antigens and play an important role in the suppression of immune responses against harmless dietary antigens and the gut microbiota. In contrast, information about the phenotype and function of Tregs in the human gut is limited. Here, we performed a detailed characterization of Foxp3+ CD4 Tregs in human small intestine (SI). SI Foxp3+ CD4 T cells were CD45RACTLA4+CD127- and suppressed proliferation of autologous T cells. Approximately $60 \%$ of SI Tregs expressed the transcription factor Helios. When stimulated, Helios- Tregs produced IL17, IFNY and IL-10, whereas Helios+ Tregs produced very low levels of these cytokines. Sampling mucosal tissue from transplanted human duodenum we demonstrated that donor SI Helios+ Tregs have a rapid turnover rate whereas Helios- Tregs persisted for at least $1 \mathrm{yr}$ post transplantation. In the normal SI, Foxp3+ Tregs constituted only $2 \%$ of all CD4 T cells, while in active celiac disease both subsets expanded 5-10-fold. Taken together, these findings suggest that human SI contains two phenotypically and functionally distinct Treg subsets (Helios+ and Helios- Tregs), which are reminiscent of rapidly renewed dietary antigen-specific Tregs and microbiota-specific Tregs resident in the mouse gut, respectively.

Keywords: regulatory T cells (Tregs); CD4 T cells; human small intestine; Foxp3+ Tregs, transplantation; Helios+ Tregs, Celiac disease 


\section{Introduction}

The intestine is a challenging environment for the local immune system, which has to respond effectively to eliminate infectious pathogens while at the same time avoiding detrimental inflammatory responses to ubiquitous food antigens and the normal gut microbiome - a function termed oral tolerance (1).The mechanisms underlying oral tolerance are not completely clear, but it is thought that Foxp3+CD4 Tregs residing in the intestinal mucosa play a central role in this process $(1,2)$.

Our current knowledge about gut Tregs is mainly derived from mouse models. Tregs are found in most organs of mice, but those residing in the intestinal mucosa appear to have gut-specific phenotypes and functions (2). While Tregs in other tissues are directed towards self-antigens (3), intestinal Tregs express a T cell receptor (TCR) repertoire specific for food and microbiota antigens (2). Intestinal Tregs therefore appear well suited to avoid unwanted immune reactions to such ubiquitous antigens $(1,2,4)$. As can be expected, the majority of Tregs in the mouse colon are microbial-specific (5-7), whereas most Tregs in the mouse SI respond to food antigens (4).

Tregs specific for exogenous antigens originate from naïve CD4 T cells that are induced in the periphery (pTregs). Retinoic acid produced by intestinal dendritic cells (DC) induces both a regulatory $T$ cell phenotype and upregulates gut homing receptors $(1,8)$. In contrast, Tregs specific for self-antigens are thymus-derived (tTregs) (3). It has been suggested that the expression of the transcription factor Helios can distinguish tTregs from pTregs, the former being Helios+ (9). However, in a recent elegant study analyzing the occurrence of Tregs specific for mucosal antigens in humans it was found that expanded memory Foxp3+ Tregs specific for grass, birch, mite and A. fumigatus all expressed high levels of Helios(8). Therefore, at least in humans, the expression of Helios does not appear to distinguish tTreg from pTregs (10).

The importance of Foxp3+ Tregs in humans is documented by the fact that mutations of the Foxp3 gene are causative of the IPEX syndrome (11). This syndrome is characterized by a detrimental inflammatory state in many organs, including the intestine. The receptor CTLA4 plays an important role for the suppressive effect of Foxp3+ Tregs, and interestingly colitis is the most prevalent adverse effect when anti-CTLA4 monotherapy is given to treat cancer 
patients $(12,13)$. Together, these findings strongly suggest that Tregs are important for maintaining homeostasis in the gut mucosa. However, studies directly examining Tregs in the human gut are scarce; in particular in the SI.

Here, we performed a detailed characterization of Treg phenotypes, functions, lifespan, and response to inflammation using clinical material from normal and transplanted SI as well as tissue from patients with active celiac disease

\section{Results}

\section{Foxp3+ CD4 Tregs are scarce but functional in the human SI}

In order to investigate the Treg population in human SI, we obtained single cells from enzyme-digested mucosal tissue from histologically normal SI as well as from colon and peripheral blood for comparison. As reported before (14), we found that about $10 \%$ of memory CD4 T cells expressed Foxp3 in peripheral blood and in the lamina propria (LP) of colonic mucosa (Fig. 1a). However, only a median of $2 \%$ of LP CD4 T cells in the SI expressed Foxp3 (Fig. 1a). We detected very few Foxp3+CD4 T cells in the epithelium (Supplementary Fig. S1) and subsequent analysis therefore focused on Tregs in LP only. Most SI Foxp3+ CD4 T cells expressed a memory Treg phenotype being CD45RA'CD127 CTLA4 ${ }^{+}$(Fig. 1b). The transcription factor Helios was expressed by approximately $60 \%$ of Tregs in the SI, which were similar to colon and somewhat lower that in peripheral blood mononuclear cells (PBMCs) (Fig. 1c). Finding that Tregs in SI were so scarce in comparison to blood and colon we analyzed whether Treg numbers depended on age. However, when examining a cohort of adults from 20-80 yrs old ( $n=33$ ) we found that the percentage of both Helios+ and HeliosFoxp3+ Tregs were independent of age in adult individuals (Supplementary Fig. S2 b and c).

To test whether SI Foxp3+ Tregs had suppressive activity, we measured their ability to inhibit T-cell proliferation when SI-derived Tregs were co-cultured with autologous naïve CD4 T cells isolated from peripheral blood. High expression of CD25 is a hallmark of Tregs, however, surface CD25 was cleaved after enzymatic treatment during the sample preparation. In order to sort Tregs based on CD25 expression, we therefore cultured tissue-derived single cells for Tregs to regain CD25 expression. After overnight culture we found that 2-3\% of CD4 T cells expressed CD25 and all of these were CD127 $7^{\text {neg }}$. Further phenotyping showed that the vast majority of $\mathrm{CD} 25+\mathrm{CD} 127^{\text {neg }}$ cells expressed Foxp3 and more than half expressed Helios; 
phenotype reminiscent of Tregs (Fig. 2a). Sorted $C D 25^{+} \mathrm{CD} 127^{\text {neg }} \mathrm{CD} 4$ Tregs were then stimulated with anti-CD3/CD28-conjugated beads for $48 \mathrm{~h}$. Naïve CD4 T cells proliferated extensively in response to CD3/CD28 TCR stimulation, but when co-cultured with activated SI-derived Tregs the proliferative response was strongly suppressed (Fig. 2b).

Together, these findings show that although less abundant than in colon and blood, Foxp3+ CD4 Tregs in human SI have strong suppressive capacity.

\section{Helios+ and Helios- Tregs display different replacement kinetics in the transplanted SI}

Studies in mice have shown that a large population of SI CD4 Tregs are dynamic cells with tissue half-life of 4-6 weeks (4). To study the turnover of Tregs in human SI we examined their replacement kinetics in transplanted duodenum. We obtained duodenal biopsies from type I diabetes patients undergoing pancreas transplantation with a duodenal segment (Fig. $3 a$ and (15)). Protocol biopsies were obtained from the duodenal graft and recipient (native) duodenum at 3, 6 and 52 weeks after transplantation. Only patients without clinical and histological signs of rejection were included. This approach provided a unique possibility to study the lifespan of tissue-resident cells directly because there is no recruitment of donor cells from the circulation (16-18). Because most donors and recipients express different HLA class I molecules, donor and recipient can be readily distinguished by flow cytometry (Fig. 3b) (16-18). We recently reported that the majority of CD8 and CD4 T cells were still of donor origin 52 weeks after transplantation (16)((19)). Here we showed that the persistency of Helios- CD4 Tregs was similar to total CD4 T cells (Fig 3c, (19)), whereas the lifespan of Helios+ CD4 Tregs was dramatically shorter with virtually no remaining cells 1 yr posttransplantation (Fig. 3c). Importantly, in the native (non-transplanted) duodenum both Treg subsets were present at all time-points (Fig. 3c).

The different turnover rate between Helios- and Helios+ Tregs may have several explanations, including different egress rate into the draining lymphatics and/or different proliferative capacity in situ. SI CD4 resident memory T (Trm) cells are CD69+ CD103+/CCR7- (19); receptors involved in retention and tissue egress $(20)(21,22))$. In order to indirectly compare the potential of the two Treg subsets to egress from the tissue we analyzed the expression of these markers on CD4 T cells isolated from histologically normal SI mucosa. Interestingly, Helios+ Tregs expressed significantly lower levels of CD69 and 
CD103 than Foxp3- CD4 T cells and Helios- Tregs, while both Tregs subsets expressed significantly more CCR7 than Foxp3- CD4 T cells (Fig. 4a). To determine their proliferative capacity we analyzed the expression of the proliferation marker Ki-67. Whereas less than $2 \%$ of Foxp3-Helios- CD4 T cells expressed Ki67, approximately 10\% of both of Treg subset expressed this marker (Fig. 4b).

Together this shows that Helios+ and Helios- Tregs have different survival rates in the transplanted SI. Helios- Tregs persist for more than one year whereas Helios+ Tregs are more rapidly depleted from the tissue. This may to some extent depend on their expression of retention and migration elements such as CD69 and CD103 and CCR7.

\section{Both SI Treg subsets increase dramatically in active celiac disease}

Next, we wanted to examine how SI Tregs responded under inflammatory conditions. To this end, we obtained SI biopsies from patients with newly diagnosed active celiac disease $(n=8)$; a common chronic inflammatory condition in human SI caused by intake of dietary gluten in genetically predisposed individuals. Analysis of tissue-derived single cell preparations from active celiac lesions showed that nearly $20 \%$ of all CD4 T cells expressed Foxp3, of which 6070\% co-expressed Helios (Fig. 5a).

We were not able to sort sufficient numbers of Tregs from celiac tissue to test their suppressive capacity. However, we and others have shown that Helios+ and Helios- Tregs can be functionally separated by their ability to produce cytokines (23-25). To test their cytokine producing capacity we stimulated tissue-derived single cells from normal SI and active celiac lesions with PMA/ionomycin. Helios+ Tregs from both normal and celiac SI produced very low levels of the cytokines measured, including IFNY, IL-17 and IL-10 (Fig 5b). In contrast, Helios- Tregs produced significant levels of all cytokines tested compared to Helios+ Tregs. Interestingly, Helios- Tregs from normal SI produced significantly more IL-17 than Foxp3- CD4 T cells and their counterparts in the celiac lesion. Moreover, a significantly higher fraction of Helios- Tregs produced IL-10 compared to Foxp3- CD4 T cells; the highest percentage found in Tregs derived from celiac lesions. Helios- Tregs produced similar amounts of IFN $y$ in normal and celiac tissue, but less than Foxp3- CD4 T cells (Fig. 5b).

Taken together, these findings show that there was a large increase in both Helios+ and Helios- Tregs in celiac lesions. Their ability to produce cytokines closely mirrored their 
bioRxiv preprint doi: https://doi.org/10.1101/2020.02.12.941369; this version posted February 12, 2020. The copyright holder for this preprint (which was not certified by peer review) is the author/funder, who has granted bioRxiv a license to display the preprint in perpetuity. It is made available under aCC-BY 4.0 International license.

counterparts in the normal SI, strongly suggesting that Foxp3+CD4 T cells in the celiac lesion are functionally similar to Foxp3+ Tregs derived from in the normal SI.

\section{Discussion}

Here we show that the human SI contains suppressive Foxp3+ CD4 Tregs that comprise two functionally distinct subsets distinguished by expression of the transcription factor Helios. Helios- Tregs show long-term residency in SI and produce substantial levels of both pro- and anti-inflammatory cytokines in response to stimulation, whereas Helios+ Tregs are rapidly replaced in the mucosa and produce very low levels of cytokines.

Recent reports have demonstrated that a large proportion of effector T cells in nonlymphoid tissues are long-lived Trm cells without the capacity to recirculate (26). However, to what extent tissue Tregs are migratory or resident is less studied. Using a unique human transplantation setting, in which a segment of the duodenum is grafted, we find that approximately $60 \%$ of CD4 T cells were still of donor origin $1 \mathrm{yr}$ after transplantation (19), suggesting that the majority of CD4 T cells are long-lived Trm cells. In this study, we find that the fraction of donor-derived Helios- CD4 Tregs constituted 1-2\% of donor CD4 T cells at 3, 6, and 52 weeks post-transplantation, demonstrating that SI Helios- Tregs are very persistent. Helios+ Tregs, in contrast, turned over much faster and at $1 \mathrm{yr}$ post-transplantation donorderived Helios+ Tregs were virtually absent in the transplanted duodenum. CD69 has been shown to inhibit lymphocyte egress from tissues (20) and whereas virtually all CD4 Trm cells expressed CD69 (19), less than 40\% of Helios+ Tregs expressed this protein. Moreover, Helios+ Tregs were virtually negative for CD103, but expressed significantly higher levels of CCR7 than CD4 Trm cells. Conversely, more than half of Helios- Tregs were CD69+, and a significant fraction expressed CD103. This phenotypic signature suggest that Helios+ Tregs may have enhanced capacity for tissue egress, which may partly explain why Helios+ Tregs were depleted much faster from the tissue than their Helios- counterparts.

A recent report studying Tregs in the SI of mice showed that SI Tregs could be separated based on their expression of the transcription factor RORyt (4). Moreover, whereas the ROR $p t+$ Tregs was induced from conventional T cells in the periphery (pTregs) by commensal microbiota, the RORyt- subset was induced by ingested protein antigens and repressed an underlying strong immunity to such proteins. Interestingly, these dietary antigen-specific 
bioRxiv preprint doi: https://doi.org/10.1101/2020.02.12.941369; this version posted February 12, 2020. The copyright holder for this preprint (which was not certified by peer review) is the author/funder, who has granted bioRxiv a license to display the preprint in perpetuity. It is made available under aCC-BY 4.0 International license.

RORyt- pTregs were continuously generated and replaced with a half-life of 4 to 6 weeks (4), reminiscent of SI Helios+ Tregs in humans. Many studies have suggested that Helios is a marker for natural (thymus-derived) tTregs (9) . However, an elegant recent study showed that the vast majority of human Tregs specific for various aeroantigens expressed Helios (8). Thus, it is tempting to speculate that SI Helios+ Tregs are human equivalents of dietary antigen-specific $\mathrm{pTregs}$ in the SI of mice.

Human SI Helios- Tregs, on the other hand, displayed turnover dynamics similar to noncirculating CD4 and CD8 Trm cells (19) (16), and persisted for $>1$ year in transplanted SI. Moreover, whereas few Helios+ Tregs produced cytokines following activation, Helios- Tregs cells produced substantial levels of IL-17, IFNy and IL-10. In fact, Helios- Tregs derived from normal SI showed higher capacity for cytokine production than their CD4 Trm counterparts. Several studies have shown that human Tregs with suppressive functions produce high levels of IL-17 (27-29), in particular in inflammatory diseases such as ulcerative colitis and Crohns disease $(27,28)$. Interestingly, it has been reported that treatment with anti-IL-17 exacerbate inflammatory bowel disease (30), suggesting that IL-17 may have a protective function in the gut. Moreover, a large fraction of IL-17-producing Helios- Tregs express the Th17 transcription factor RORyt, both in the human and mouse gut $(29,31)$. In contrast to dietary antigen-specific RORyt-pTregs (4), RORyt + Tregs in the intestine of mice are microbiota-specific $(4,32)$ and this subset has been shown produce IL-17 in the SI, but not in the colon (31).

IL-10 is thought to play an important role in Treg-mediated suppression. Surprisingly, very few SI Tregs produced IL-10 in response to activation, compared to Tregs in colon and airway mucosa $(25,33)$. Interestingly, when IL-10 was selectively deleted in Foxp3+ Tregs in mice, the animals developed severe colitis and inflammation in the lungs, but no overt inflammation in the SI (34). Moreover, inherited deficiencies of IL-10 orIL-10 receptor lead to life-threatening early onset colitis and airway inflammation, but no inflammation in the SI (35). In the latter situation allogeneic stem cell transplantation proved to be effective, indicating that the IL-10/IL-10 receptor deficiency affects hematopoietic cells (35). Also, IL-10 producing Foxp3-CD4 T cells, termed Tr1 cells, were found to be very infrequent in the SI in comparison to the colon and nasal mucosa $(25,33)$. Together, this suggests that IL-10, produced by Tregs and Tr1, play a less important role to maintain homeostasis in the SI 
compared with other mucosal sites. It is well documented that the microbiota regulates the number and function of intestinal Tregs (32), and given the enormously different numbers of commensal bacteria between the SI and colon (36), this may explain why the density of Tregs and their capacity to produce IL-10 is lower in the SI.

Tregs in the SI of human adults (>20 yrs of age) constituted only $2 \%$ of all CD4 T cells, which is very low compared to approximately $5-10 \%$ in colon and other peripheral tissues $(25,37)$. However, in a recent study comparing tissue-resident Tregs in pediatric and adult organ donors it was found that the fractions of Tregs were age-dependent (38). In fact, the percentage of Tregs in the SI of infants under 2 yrs were $15-20 \%$ of all CD4 T cells, whereas adult SI contained approximately $2 \%$ of CD4 T cells as Tregs. Together, these results suggest that maintenance of homeostasis (oral tolerance) in the SI is less dependent on Tregs in adulthood compared with the first years of life.

In striking contrast, we found that the number of Tregs increased dramatically in active celiac disease lesions and constituted almost $20 \%$ of total CD4 T cells. A role for Tregs in celiac disease has been disputed, but a recent study reported that the vast majority of gluten-specific CD4 T cells in blood of gluten-challenged celiac patients were Foxp3+ Tregs, albeit with impaired suppressive function (39). Other studies have shown a similar increase of Foxp3+ Tregs numbers in the celiac lesion, and found that the suppressive action of Tregs is reduced by local production of IL-15 (40). Our study clearly shows that SI Tregs are highly expanded in response to inflammation, and in active celiac disease both Tregs and Foxp3CD4 T cells (putative Tr1) contained significantly higher fractions of IL-10 producing cells than in normal tissue.

Together, in line with the current knowledge about the function of Treg populations in the mouse gut, we show that the human SI contains two distinct Treg subsets: a dynamic population of Helios+ Tregs that may play an important role in tolerance to food antigens, and a population of tissue-resident Helios- Tregs that contribute to immune tolerance to the gut microbiota. Differences in Treg abundance and functions between different mucosal sites should be taken into consideration when Tregs are targeted to treat inflammatory disorders. 


\section{Materials and methods}

\section{Subjects and biological material}

Proximal jejunum tissue was resected from non-pathological SI during surgery for cancer in the pancreas or distal bile duct with a Whipple procedure (pancreatoduodenectomy) $(n=18)$ or from donor and recipient duodenum during pancreas transplantation of type I diabetes mellitus patients (donors: $n=14$; recipients, $n=12$; Horneland et al., 2015). Endoscopic biopsies were obtained from donor and patient duodenum at 3, 6, and $52 \mathrm{wk}$ after transplantation. Colonic biopsies were obtained by colonoscopy of individuals with unexplained stomach pain with normal histology $(n=3)$. All samples were evaluated by an experienced pathologist and only material with normal histology was included. Duodenal biopsies were also obtained from newly diagnosed untreated celiac patients $(n=8)$. The study was approved by the Regional Committee for Medical Research Ethics in Southeast Norway (\# 2012/341, 2010/2720, and 2012/2278) and the Privacy Ombudsman for Research at Oslo University Hospital-Rikshospitalet and complies with the Declaration of Helsinki. All participants gave their written informed consent. Resected SI was opened longitudinally and rinsed thoroughly in PBS, and mucosal folds were dissected off the submucosa. To obtain single-cell suspensions, epithelial cells were removed by washing in PBS containing $2 \mathrm{mM}$ EDTA three times for $20 \mathrm{~min}$ at $37^{\circ} \mathrm{C}$, and the lamina propria was minced and digested in RPMI medium containing $2.5 \mathrm{mg} / \mathrm{ml}$ Liberase and $20 \mathrm{U} / \mathrm{ml}$ DNase I (both from Roche) at $37^{\circ} \mathrm{C}$ for $1 \mathrm{~h}$. Digested tissue was passed through 100- $\mu \mathrm{m}$ cell strainers (Falcon) and washed three times in PBS. PBMC were isolated by lymphoprep gradient centrifugation of blood from patients or buffycoats from healthy donors from the Oslo University Hospital Blood Center. Identically treated PBMCs served as controls for the effect of collagenase on epitopes recognized by antibodies used in flow cytometry.

\section{Flow cytometric analysis}

Cells were stained with Fixable Viability Dye eFluor $780\left(1 \mu \mathrm{l} / 10^{6}\right.$ cells, eBioscience, San Diego, CA) for $30 \mathrm{~min}$ at $4^{\circ} \mathrm{C}$, followed by surface staining with antibodies to CD3 (clone SK7), CD4 (clone OKT4), CD8 (clone SK1) and CD127 (clone M21). To detect intracellular cytokines, cells were treated with FOXP3/transcription factor staining buffer set according to the manufacturers protocol (eBioscience) and stained with antibodies to FOXP3 (clone 236A/E7), 
Helios (clone 22F6), and IL-17 (clone 64DEC) from eBioscience, or CTLA-4 (clone L3DTO), IFNg (clone 4S.B3), and IL-10 (clone JES3-9D7) from Biolegend. All antibodies were incubated for $30 \mathrm{~min}$ at $4^{\circ} \mathrm{C}$. Flow cytometry was performed on a BD LSRFortessa (BD Biosciences), and analyzed using FlowJo 10.3 software (Tree Star, Eugene, OR). Gates for surface markers were set based on FMO controls, and cytokines gates was based on untreated cells.

\section{Cytokine analysis}

To assess the cytokine production by mucosal T cells, dispersed cells were cultured for $4 \mathrm{~h}$ in $\mathrm{RPMI} / 10 \%$ fetal calf serum (FCS) with $1.5 \mathrm{ng} / \mathrm{ml}$ phorbol 12 -myristate 13 -acetate (PMA) and $1 \mu \mathrm{g} / \mathrm{ml}$ ionomycin (all from Sigma-Aldrich, St Louis, Mo) with Golgi-Stop (BD Bioscience, San Jose, $\mathrm{CA}$ ) added after $1 \mathrm{~h}$ of stimulation to allow intracellular accumulation of cytokines.

\section{Treg suppression assay}

Tregs were defined as $\mathrm{CD} 25^{+} \mathrm{CD} 127^{-} \mathrm{CD} 4^{+} \mathrm{T}$ cells. Autologous $\mathrm{CD} 25^{-} \mathrm{CD} 127^{+} \mathrm{CD} 45 \mathrm{RA}^{+}$naïve CD4+ T cells were used as responder T cells (Tresp). Sorted Tregs were pre-activated for $48 \mathrm{~h}$ using $\alpha-C D 3 / C D 28$ coated beads (Dynabeads Human T-Activator, Thermo Fisher scientific) in a 1:1 ratio (beads to cells). Tregs and CFSE- (1.5 $\mu \mathrm{M}$, Thermo Fisher scientific) labeled Tresp cells were mixed in a 1:2 (Treg:Tresp) ratio and stimulated with $\alpha$-CD3/CD28 coated beads in a 1:2 ratio (beads:cells). CFSE dilution in Tresp was analyzed after 4 days of co-culture by flow cytometry.

\section{Figure Legends}

Fig. 1: CD4 Tregs are scarce in the SI. a) Representative contour plots showing the expression of CD4 and Foxp3 on CD3+ T cells in the lamina propria (LP) SI, colon, and PBMCS (gated on CD45RO). Compiled data are shown (right panel, gated on CD4). b) Representative contour plots showing the expression of Foxp3, CD45RA, CD127 and CTLA-4 in SI (LP) CD4+ T cells. c) Representative contour plots showing the expression of Helios and Foxp3 on CD4+ T cells from SI (LP), colon and PBMCs (gated on CD45RO). Compiled data are shown (right panel, gated on Foxp3+CD4 T cells). One-way ANOVA with Dunnett's multiple comparisons test, $* * * \mathrm{p}<0.001$; non significant (ns).

Fig. 2: SI Tregs suppress autologous naïve T cells. a) Contour plot showing the expression of CD127 and CD25 on SI CD4 T cells cultured overnight (left) and expression of Foxp3 and 
Helios gated on CD25+CD127- cells (right). b) Histograms showing the expression of CFSE on blood-derived CFSE-labelled conventional CD4 T cells (CD25 CD $\left.127^{+} \mathrm{CD}^{-} 5 \mathrm{RA}^{+}\right)$stimulated with CD3/CD28 beads for 4 days without (left) or with autologous SI -derived Tregs $\left(\mathrm{CD} 25^{+} \mathrm{CD} 127^{-} \mathrm{CD} 4^{+}\right)$. Representative of three independent experiments.

Fig. 3: Helios+ Tregs are short-lived in transplanted SI. a) Drawing showing the pancreaticoduodenal transplantation procedure. b) Donor and recipient Foxp3+CD4 T cells in transplanted duodenum were distinguished based on disparate HLA class I. Representative contour plot showing the expression of Helios and HLA-A3 on SI-derived Foxp3+ CD4 T cells 52 weeks after transplantation (donor $\mathrm{HLA}^{-\mathrm{A}^{+}}{ }^{+}$; recipient $\mathrm{HLA}^{-\mathrm{A} 3^{-}}{ }^{-}$. c) Percentage of Helios+Foxp3+ and Helios- Foxp3+ CD4 T cells in transplanted (left, gated on donor CD4 T cells) and recipient duodenum (right), respectively, at 0, 3, 6, and 52 weeks after transplantation. One-way ANOVA with Dunnett's multiple comparisons test, ${ }^{* * *} p<0.001$; $* p<0.05$; non significant (ns).

Fig. 4: Helios+ Tregs express less CD69 and CD103 and more CCR7 than Trm cells. a) Representative contour plots of SI-derived cells showing the expression of Foxp3, CD69, CD103, and CCR7 on CD4 T cells (upper) and expression of Helios, CD69, CD103, and CCR7 on Foxp3+ CD4 T cells (middle). Compiled data are shown (lower). b) Representative contour plots showing the expression of Ki67 on SI-derived CD4 and Foxp3+ CD4 T cells. Compiled data are shown (right). One-way ANOVA with Dunnett's multiple comparisons test, $* * *$ $\mathrm{p}<0.001 ;{ }^{* *} \mathrm{p}<0.01 ;{ }^{*} \mathrm{p}<0.05$; non significant (ns).

Fig. 5: Helios+Foxp3+ and Helios-Foxp3+CD4 T cells are dramatically increased in untreated celiac disease. a) Representative contour plots showing expression of Helios and Foxp3 on CD4 T cells derived from normal SI (left) and untreated celiac disease (right). Compiled data are shown (lower). b) Cytokine production in Foxp3-Helios-, Foxp3+Helios+, and Foxp3+Helios- CD4 T cells derived from normal and untreated celiac SI following $4 \mathrm{~h}$ stimulation with PMA/ionomycin. Student's t-test, ${ }^{* * *} p<0.001 ;{ }^{* *} p<0.01 ;{ }^{*} p<0.05$; non significant (ns). 
bioRxiv preprint doi: https://doi.org/10.1101/2020.02.12.941369; this version posted February 12,2020 . The copyright holder for this preprint (which was not certified by peer review) is the author/funder, who has granted bioRxiv a license to display the preprint in perpetuity. It is made available under aCC-BY 4.0 International license.

\section{References:}

1. Mowat AM. 2018. To respond or not to respond - a personal perspective of intestinal tolerance. Nat Rev Immunol 18: 405-15

2. Tanoue T, Atarashi K, Honda K. 2016. Development and maintenance of intestinal regulatory T cells. Nat Rev Immunol 16: 295-309

3. Sakaguchi S, Powrie F, Ransohoff RM. 2012. Re-establishing immunological self-tolerance in autoimmune disease. Nat Med 18: 54-8

4. Kim KS, Hong SW, Han D, Yi J, Jung J, Yang BG, Lee JY, Lee M, Surh CD. 2016. Dietary antigens limit mucosal immunity by inducing regulatory T cells in the small intestine. Science 351: 85863

5. Atarashi K, Tanoue T, Shima T, Imaoka A, Kuwahara T, Momose $Y$, Cheng G, Yamasaki S, Saito T, Ohba Y, Taniguchi T, Takeda K, Hori S, Ivanov, II, Umesaki Y, Itoh K, Honda K. 2011. Induction of colonic regulatory $T$ cells by indigenous Clostridium species. Science 331: 337-41

6. Campbell C, Dikiy S, Bhattarai SK, Chinen T, Matheis F, Calafiore M, Hoyos B, Hanash A, Mucida D, Bucci V, Rudensky AY. 2018. Extrathymically Generated Regulatory T Cells Establish a Niche for Intestinal Border-Dwelling Bacteria and Affect Physiologic Metabolite Balance. Immunity 48: 1245-57 e9

7. Lathrop SK, Bloom SM, Rao SM, Nutsch K, Lio CW, Santacruz N, Peterson DA, Stappenbeck TS, Hsieh CS. 2011. Peripheral education of the immune system by colonic commensal microbiota. Nature 478: 250-4

8. Bacher P, Heinrich F, Stervbo U, Nienen M, Vahldieck M, Iwert C, Vogt K, Kollet J, Babel N, Sawitzki B, Schwarz C, Bereswill S, Heimesaat MM, Heine G, Gadermaier G, Asam C, Assenmacher M, Kniemeyer O, Brakhage AA, Ferreira F, Wallner M, Worm M, Scheffold A. 2016. Regulatory T Cell Specificity Directs Tolerance versus Allergy against Aeroantigens in Humans. Cell 167: 1067-78.e16

9. Thornton AM, Korty PE, Tran DQ, Wohlfert EA, Murray PE, Belkaid Y, Shevach EM. 2010. Expression of Helios, an Ikaros transcription factor family member, differentiates thymicderived from peripherally induced Foxp3+ T regulatory cells. Journal of immunology 184: 3433-41

10. Thornton AM, Shevach EM. 2019. Helios: still behind the clouds. Immunology 158: 161-70

11. Bennett CL, Christie J, Ramsdell F, Brunkow ME, Ferguson PJ, Whitesell L, Kelly TE, Saulsbury FT, Chance PF, Ochs HD. 2001. The immune dysregulation, polyendocrinopathy, enteropathy, X-linked syndrome (IPEX) is caused by mutations of FOXP3. Nat Genet 27: 20-1

12. Alissafi T, Hatzioannou A, Legaki Al, Varveri A, Verginis P. 2019. Balancing cancer immunotherapy and immune-related adverse events: The emerging role of regulatory $T$ cells. J Autoimmun 104: 102310

13. Hodi FS, O'Day SJ, McDermott DF, Weber RW, Sosman JA, Haanen JB, Gonzalez R, Robert C, Schadendorf D, Hassel JC, Akerley W, van den Eertwegh AJ, Lutzky J, Lorigan P, Vaubel JM, Linette GP, Hogg D, Ottensmeier CH, Lebbe C, Peschel C, Quirt I, Clark JI, Wolchok JD, Weber JS, Tian J, Yellin MJ, Nichol GM, Hoos A, Urba WJ. 2010. Improved survival with ipilimumab in patients with metastatic melanoma. N Engl J Med 363: 711-23

14. Saito T, Nishikawa H, Wada H, Nagano Y, Sugiyama D, Atarashi K, Maeda Y, Hamaguchi M, Ohkura N, Sato E, Nagase H, Nishimura J, Yamamoto H, Takiguchi S, Tanoue T, Suda W, Morita H, Hattori M, Honda K, Mori M, Doki Y, Sakaguchi S. 2016. Two FOXP3(+)CD4(+) T cell subpopulations distinctly control the prognosis of colorectal cancers. Nat Med 22: 679-84

15. Horneland R, Paulsen V, Lindahl JP, Grzyb K, Eide TJ, Lundin K, Aabakken L, Jenssen T, Aandahl EM, Foss A, Oyen O. 2015. Pancreas transplantation with enteroanastomosis to native duodenum poses technical challenges--but offers improved endoscopic access for scheduled biopsies and therapeutic interventions. Am J Transplant 15: 242-50 
bioRxiv preprint doi: https://doi.org/10.1101/2020.02.12.941369; this version posted February $12,2020$. The copyright holder for this preprint (which was not certified by peer review) is the author/funder, who has granted bioRxiv a license to display the preprint in perpetuity. It is made available under aCC-BY 4.0 International license.

16. Bartolome-Casado R, Landsverk OJB, Chauhan SK, Richter L, Phung D, Greiff V, Risnes LF, Yao Y, Neumann RS, Yaqub S, Oyen O, Horneland R, Aandahl EM, Paulsen V, Sollid LM, Qiao SW, Baekkevold ES, Jahnsen FL. 2019. Resident memory CD8 T cells persist for years in human small intestine. J Exp Med 216: 2412-26

17. Bujko A, Atlasy N, Landsverk OJB, Richter L, Yaqub S, Horneland R, Oyen O, Aandahl EM, Aabakken L, Stunnenberg HG, Baekkevold ES, Jahnsen FL. 2018. Transcriptional and functional profiling defines human small intestinal macrophage subsets. J Exp Med 215: 44158

18. Landsverk OJ, Snir O, Casado RB, Richter L, Mold JE, Reu P, Horneland R, Paulsen V, Yaqub S, Aandahl EM, Oyen OM, Thorarensen HS, Salehpour M, Possnert G, Frisen J, Sollid LM, Baekkevold ES, Jahnsen FL. 2017. Antibody-secreting plasma cells persist for decades in human intestine. J Exp Med 214: 309-17

19. Bartolome-Casado R, Landsverk OJB, Chauhan SK, Yaqub S, Oyen O, Horneland R, Aandahl EM, Paulsen V, Baekkevold ES, Jahnsen FL. 2019. CD4+ T cells persist for years in the human small intestine and mediate robust TH1 immunity. BioRxiv

20. Shiow LR, Rosen DB, Brdickova N, Xu Y, An J, Lanier LL, Cyster JG, Matloubian M. 2006. CD69 acts downstream of interferon-alpha/beta to inhibit S1P1 and lymphocyte egress from lymphoid organs. Nature 440: 540-4

21. Baekkevold ES, Yamanaka T, Palframan RT, Carlsen HS, Reinholt FP, von Andrian UH, Brandtzaeg P, Haraldsen G. 2001. The ccr7 ligand elc (ccl19) is transcytosed in high endothelial venules and mediates T cell recruitment. J Exp Med 193: 1105-12.

22. Cepek KL, Shaw SK, Parker CM, Russell GJ, Morrow JS, Rimm DL, Brenner MB. 1994. Adhesion between epithelial cells and T lymphocytes mediated by E-cadherin and the alpha E beta 7 integrin. Nature 372: 190-3

23. Raffin C, Pignon P, Celse C, Debien E, Valmori D, Ayyoub M. 2013. Human Memory HeliosFOXP3+ Regulatory T Cells (Tregs) Encompass Induced Tregs That Express Aiolos and Respond to IL-1beta by Downregulating Their Suppressor Functions. Journal of immunology 191: 461927

24. Mercer F, Khaitan A, Kozhaya L, Aberg JA, Unutmaz D. 2014. Differentiation of IL-17producing effector and regulatory human $T$ cells from lineage-committed naive precursors. J Immunol 193: 1047-54

25. Ballke C, Gran E, Baekkevold ES, Jahnsen FL. 2016. Characterization of Regulatory T-Cell Markers in CD4+ T Cells of the Upper Airway Mucosa. PLoS One 11: e0148826

26. Masopust D, Soerens AG. 2019. Tissue-Resident T Cells and Other Resident Leukocytes. Annu Rev Immunol 37: 521-46

27. Hovhannisyan Z, Treatman J, Littman DR, Mayer L. 2011. Characterization of interleukin-17producing regulatory $T$ cells in inflamed intestinal mucosa from patients with inflammatory bowel diseases. Gastroenterology 140: 957-65

28. Jung MK, Kwak JE, Shin EC. 2017. IL-17A-Producing Foxp3(+) Regulatory T Cells and Human Diseases. Immune Netw 17: 276-86

29. Pesenacker AM, Broady R, Levings MK. 2015. Control of tissue-localized immune responses by human regulatory T cells. Eur J Immunol 45: 333-43

30. Pappu R, Rutz S, Ouyang W. 2012. Regulation of epithelial immunity by IL-17 family cytokines. Trends Immunol 33: 343-9

31. Sefik E, Geva-Zatorsky N, Oh S, Konnikova L, Zemmour D, McGuire AM, Burzyn D, Ortiz-Lopez A, Lobera M, Yang J, Ghosh S, Earl A, Snapper SB, Jupp R, Kasper D, Mathis D, Benoist C. 2015. MUCOSAL IMMUNOLOGY. Individual intestinal symbionts induce a distinct population of RORgamma(+) regulatory T cells. Science 349: 993-7

32. Hegazy AN, Powrie F. 2015. MICROBIOME. Microbiota RORgulates intestinal suppressor T cells. Science 349: 929-30

33. Alfen JS, Larghi P, Facciotti F, Gagliani N, Bosotti R, Paroni M, Maglie S, Gruarin P, Vasco CM, Ranzani V, Frusteri C, Iseppon A, Moro M, Crosti MC, Gatti S, Pagani M, Caprioli F, Abrignani 
bioRxiv preprint doi: https://doi.org/10.1101/2020.02.12.941369; this version posted February 12, 2020. The copyright holder for this preprint (which was not certified by peer review) is the author/funder, who has granted bioRxiv a license to display the preprint in perpetuity. It is made available under aCC-BY 4.0 International license.

S, Flavell RA, Geginat J. 2018. Intestinal IFN-gamma-producing type 1 regulatory T cells coexpress CCR5 and programmed cell death protein 1 and downregulate IL-10 in the inflamed guts of patients with inflammatory bowel disease. J Allergy Clin Immunol 142: 153747 e8

34. Rubtsov YP, Rasmussen JP, Chi EY, Fontenot J, Castelli L, Ye X, Treuting P, Siewe L, Roers A, Henderson WR, Jr., Muller W, Rudensky AY. 2008. Regulatory T cell-derived interleukin-10 limits inflammation at environmental interfaces. Immunity 28: 546-58

35. Engelhardt KR, Shah N, Faizura-Yeop I, Kocacik Uygun DF, Frede N, Muise AM, Shteyer E, Filiz S, Chee R, Elawad M, Hartmann B, Arkwright PD, Dvorak C, Klein C, Puck JM, Grimbacher B, Glocker EO. 2013. Clinical outcome in IL-10- and IL-10 receptor-deficient patients with or without hematopoietic stem cell transplantation. J Allergy Clin Immunol 131: 825-30

36. Mowat AM, Agace WW. 2014. Regional specialization within the intestinal immune system. Nat Rev Immunol 14: 667-85

37. Sharabi A, Tsokos MG, Ding Y, Malek TR, Klatzmann D, Tsokos GC. 2018. Regulatory T cells in the treatment of disease. Nat Rev Drug Discov 17: 823-44

38. Thome JJ, Bickham KL, Ohmura Y, Kubota M, Matsuoka N, Gordon C, Granot T, Griesemer A, Lerner H, Kato T, Farber DL. 2016. Early-life compartmentalization of human T cell differentiation and regulatory function in mucosal and lymphoid tissues. Nat Med 22: 72-7

39. Cook L, Munier CML, Seddiki N, van Bockel D, Ontiveros N, Hardy MY, Gillies JK, Levings MK, Reid HH, Petersen J, Rossjohn J, Anderson RP, Zaunders JJ, Tye-Din JA, Kelleher AD. 2017. Circulating gluten-specific FOXP3(+)CD39(+) regulatory T cells have impaired suppressive function in patients with celiac disease. J Allergy Clin Immunol 140: 1592-603 e8

40. Zanzi D, Stefanile R, Santagata S, laffaldano L, laquinto G, Giardullo N, Lania G, Vigliano I, Vera AR, Ferrara K, Auricchio S, Troncone R, Mazzarella G. 2011. IL-15 interferes with suppressive activity of intestinal regulatory $\mathrm{T}$ cells expanded in Celiac disease. Am J Gastroenterol 106: 1308-17

\section{Acknowledgements}

We are grateful to Kjersti Thorvaldsen Hagen, and Kathrine Hagelsteen for excellent technical assistance; the staff at Gastrolab, the surgical surgical staff, (Oslo University Hospital; Christian Naper (Dept of Immunology) for providing HLA-typing, and Flow Cytometry Core Facility (all at Oslo University Hospital). This study was supported by grants from the Research Council of Norway through its Centres of Excellence funding scheme (179573) and the research leading to these results has received funding from the European Union Seventh Framework Programme (FP7-PEOPLE-2013-COFUND) under grant agreement $n^{\circ} 609020$ - Scientia Fellows. 
bioRxiv preprint doi: https://doi.org/10.1101/2020.02.12.941369; this version posted February 12, 2020. The copyright holder for this

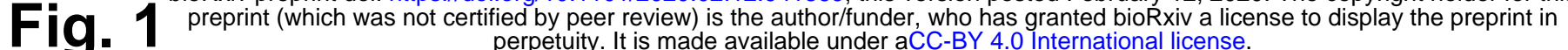

a
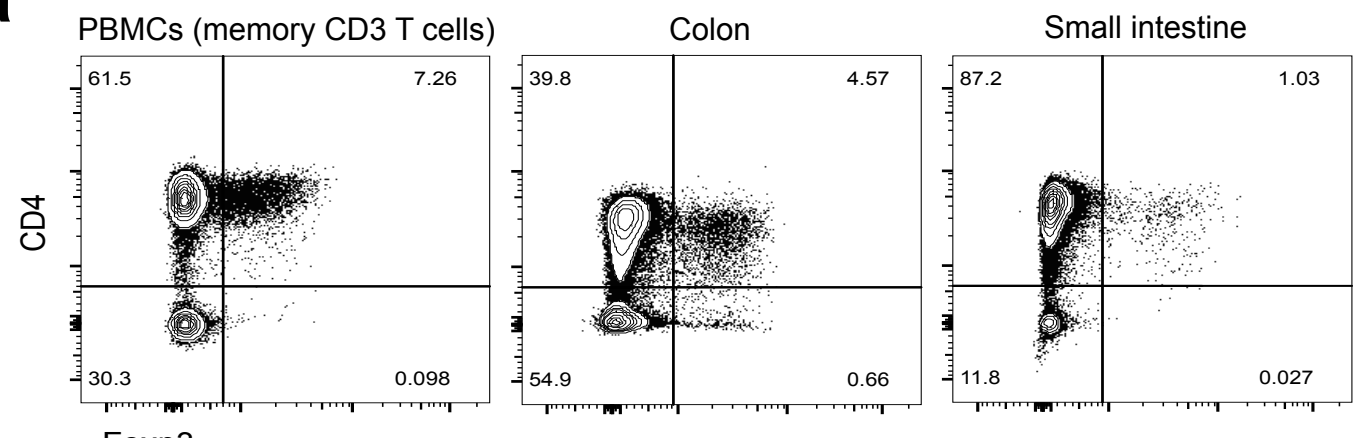

b
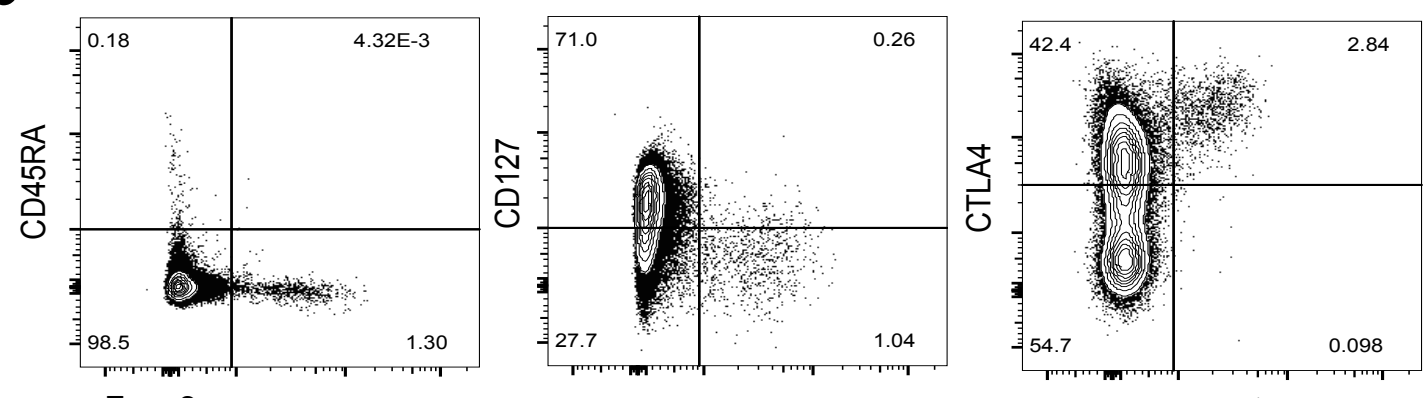

Foxp3

C
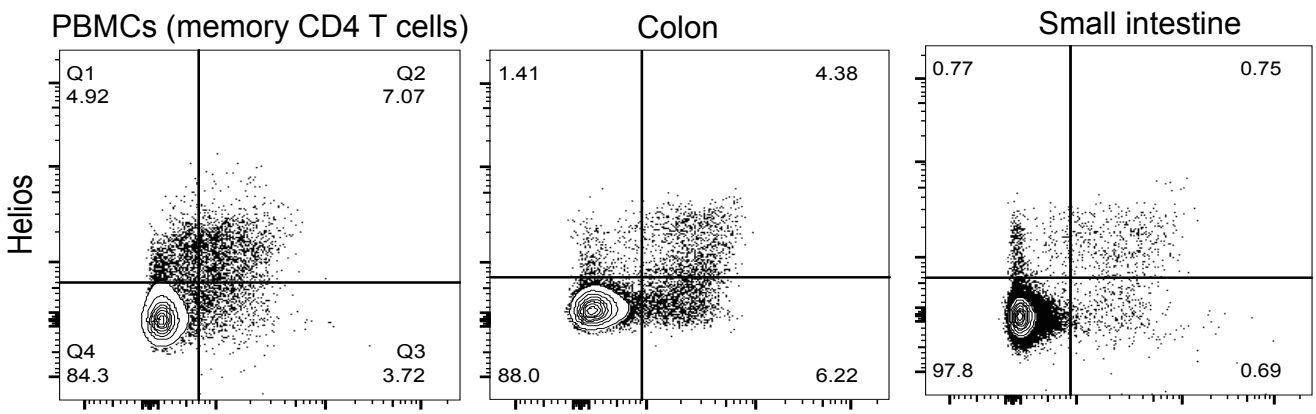

Foxp3
Gated on CD4+ T cells

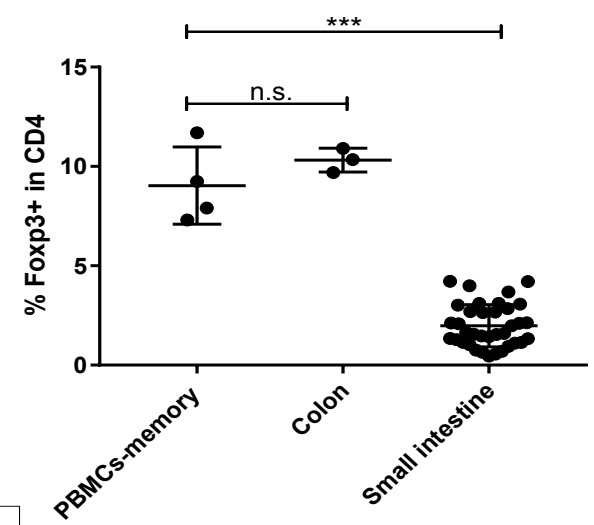

Gated on Foxp3+CD4+ T cells n.s.

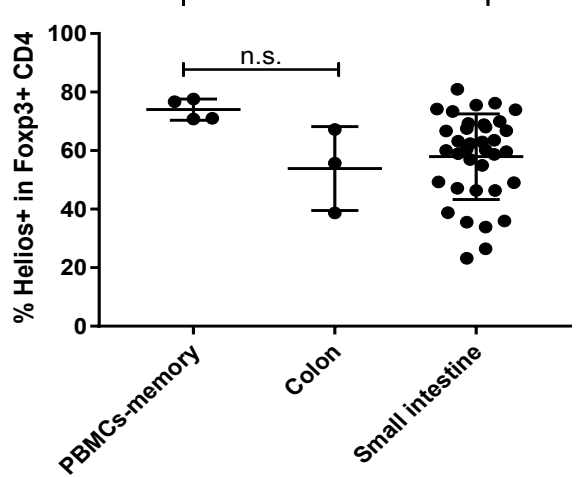


- DioRxiv preprint doi: https://doi.org/10.1101/2020.02.12.941369; this version posted February 12, 2020. The copyright holder for this 2 preprint (which was not certified by peer review) is the author/funder, who has granted bioRxiv a license to display the preprint in perpetuity. It is made available under aCC-BY 4.0 International license.

a

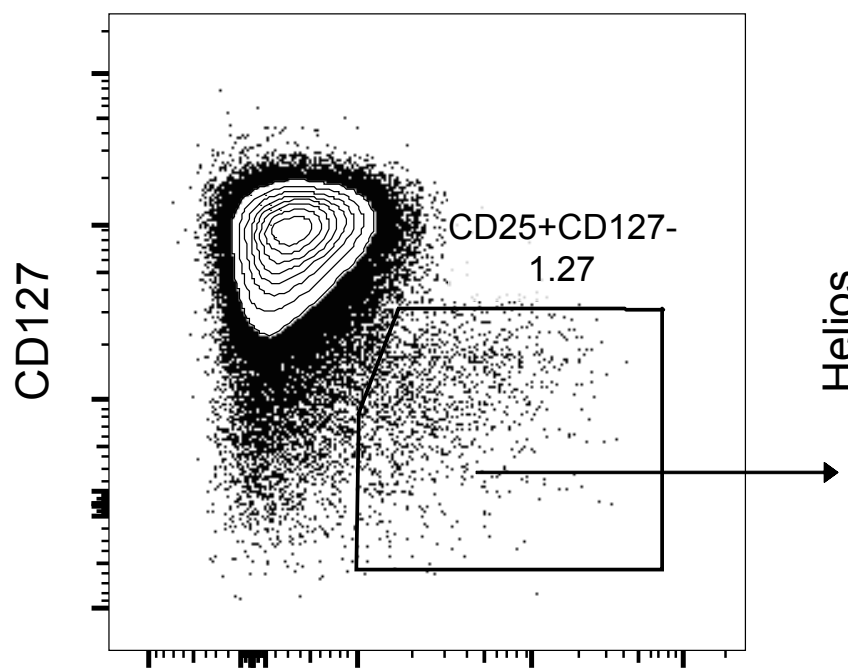

CD25

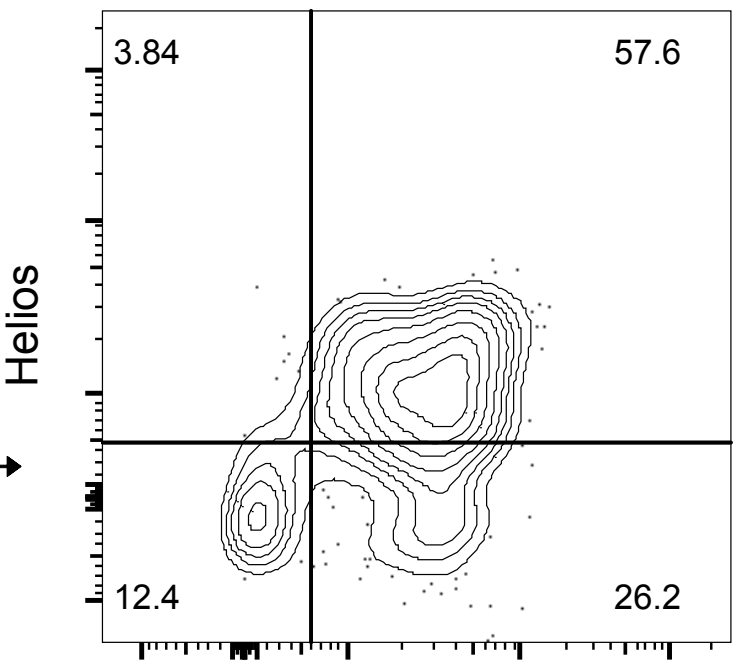

Foxp3

b
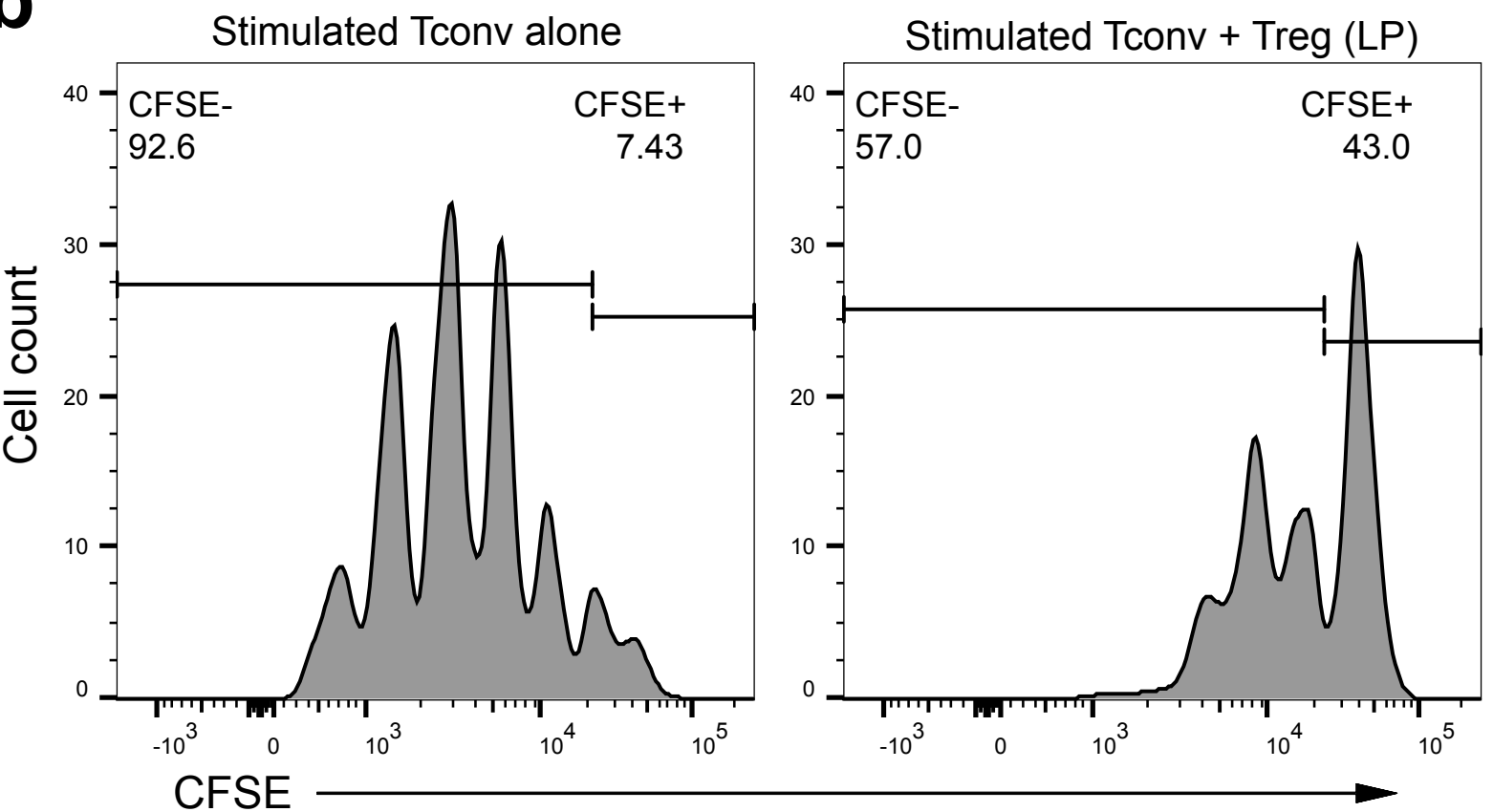

CFSE 


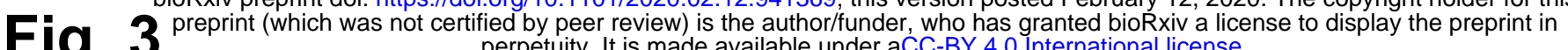

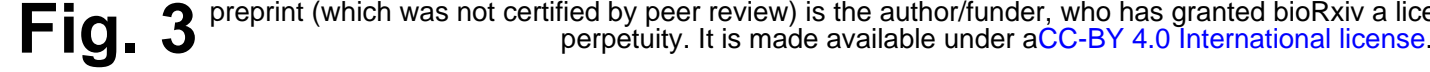

a

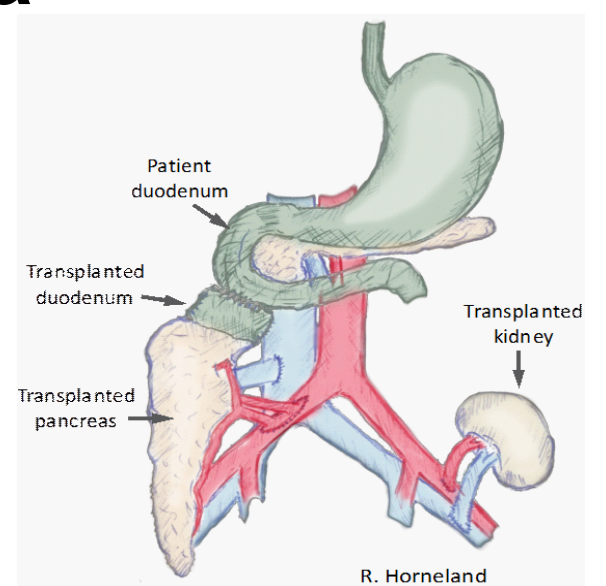

C

Donor CD4+ T cells (graft)
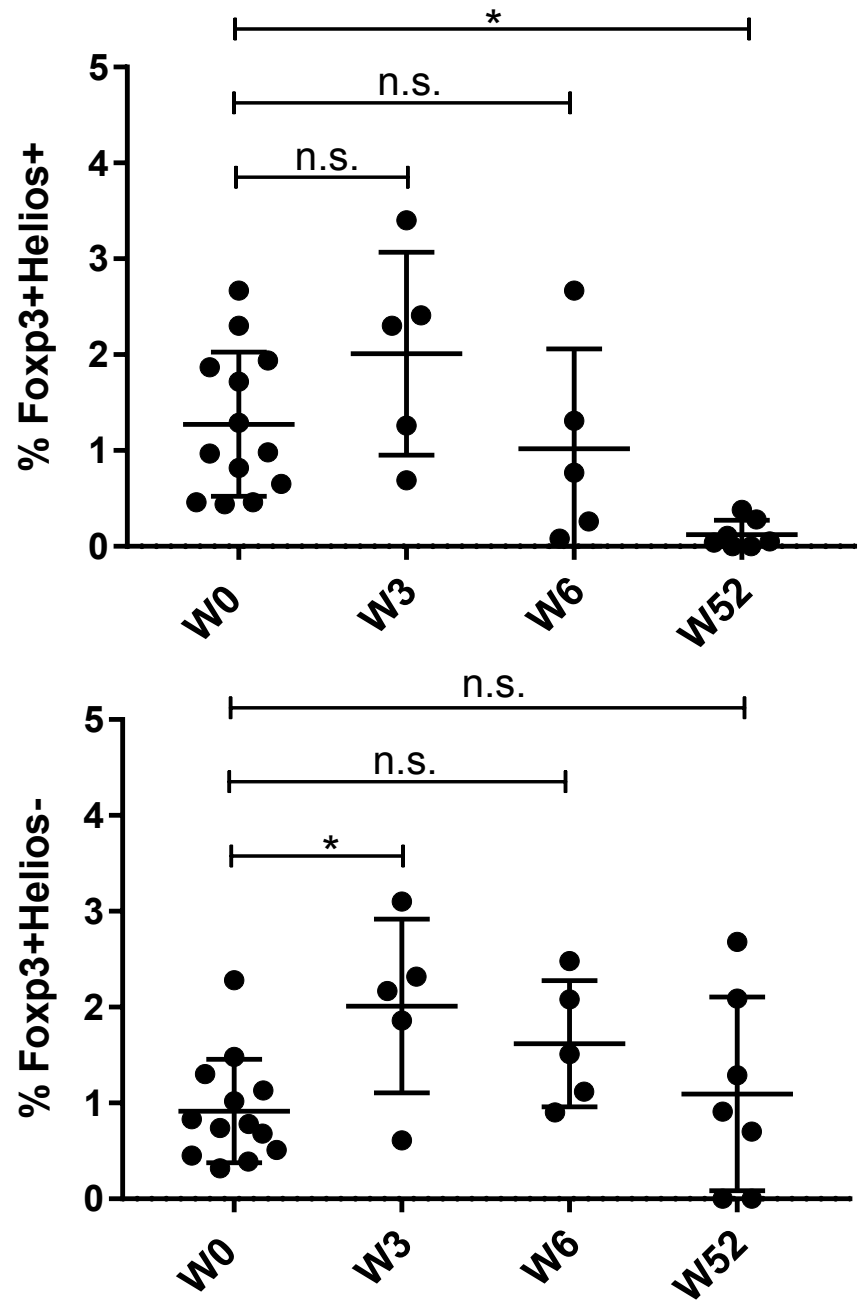

b CD4+Foxp3+ T cells in Transplanted duodenum (52 weeks post-transplantation)

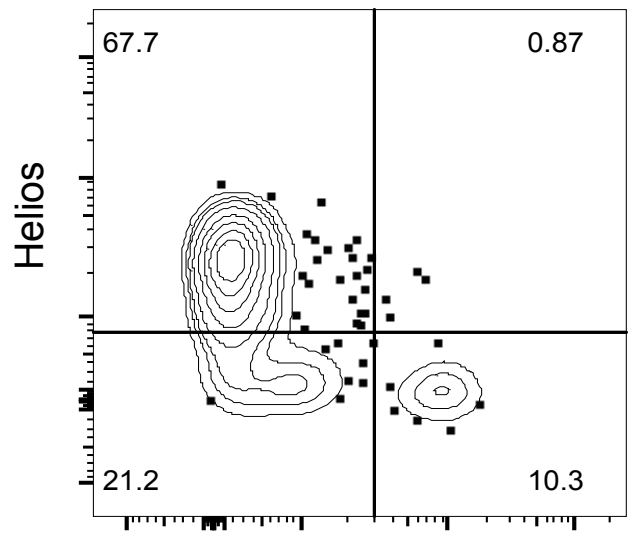

HLA-A3
CD4+ $T$ cells (Native duodenum)
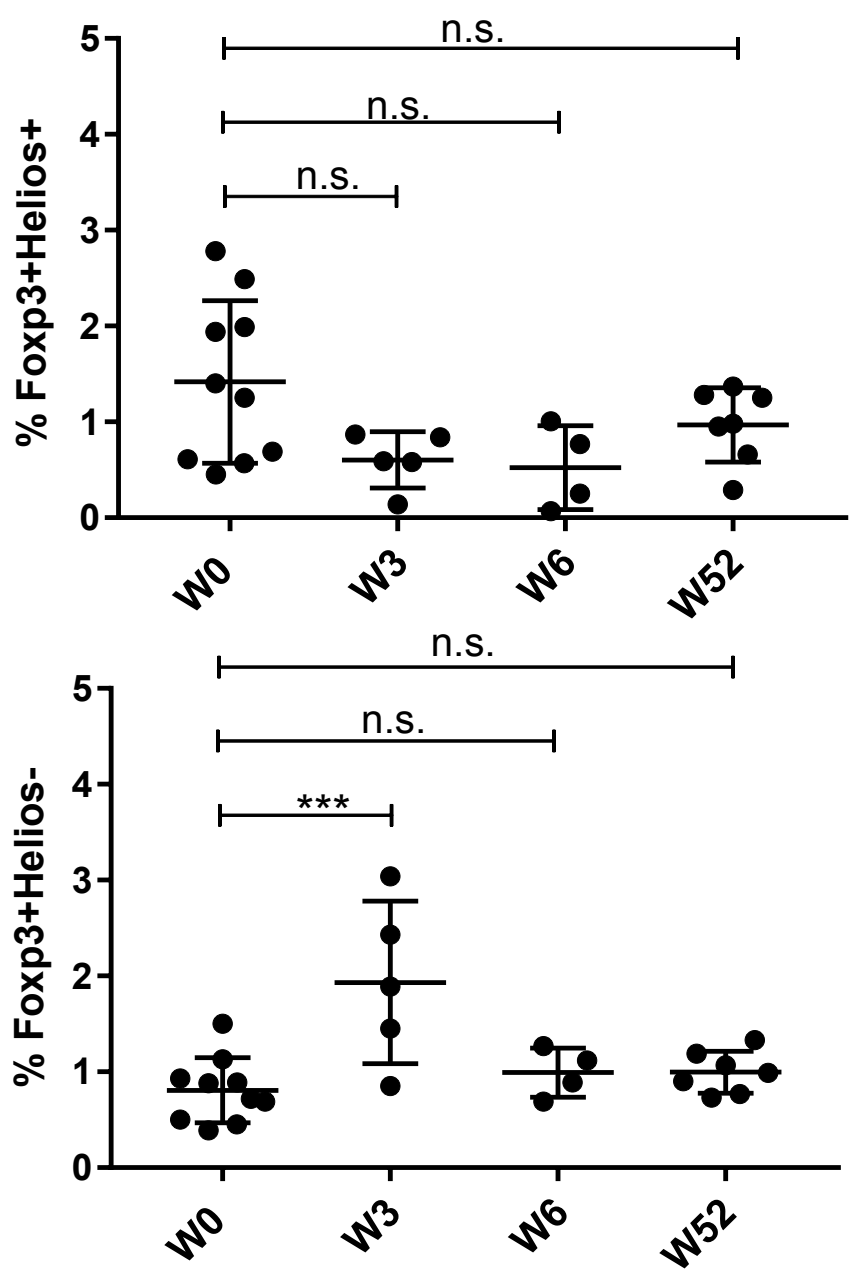


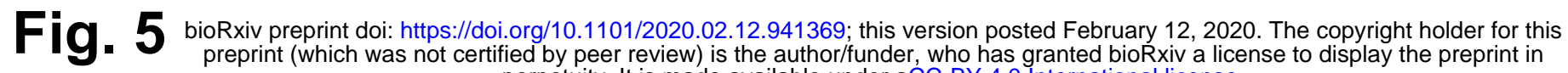

10. 5 bioRxiv preprint doi: https://doi.org/10.1101/2020.02.12.941369; this version posted February $12,2020$. The copyright holder for this
preprint (which was not certified by peer review) is the author/funder, who has granted bioRxiv a license to display the preprint in perpetuity. It is made available under aCC-BY 4.0 International license.

a

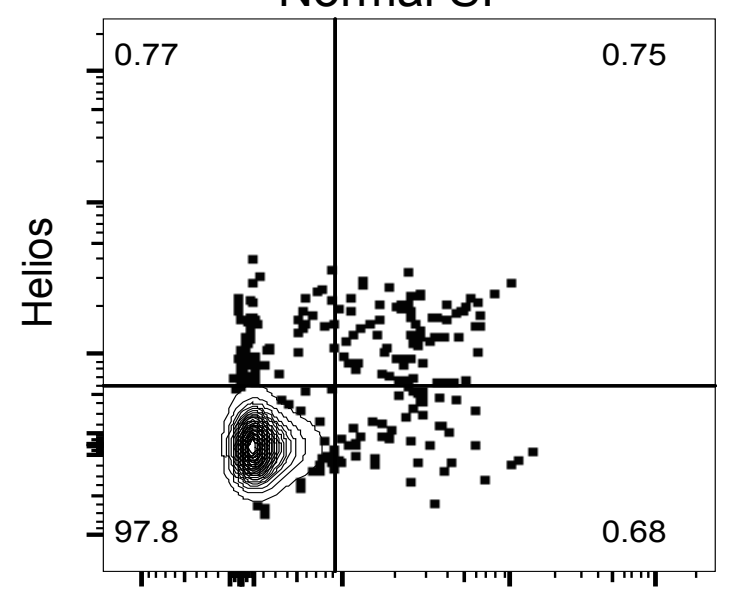

Foxp3

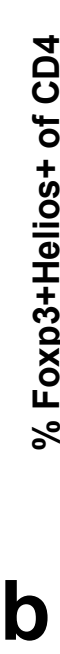

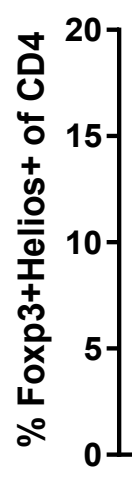

b
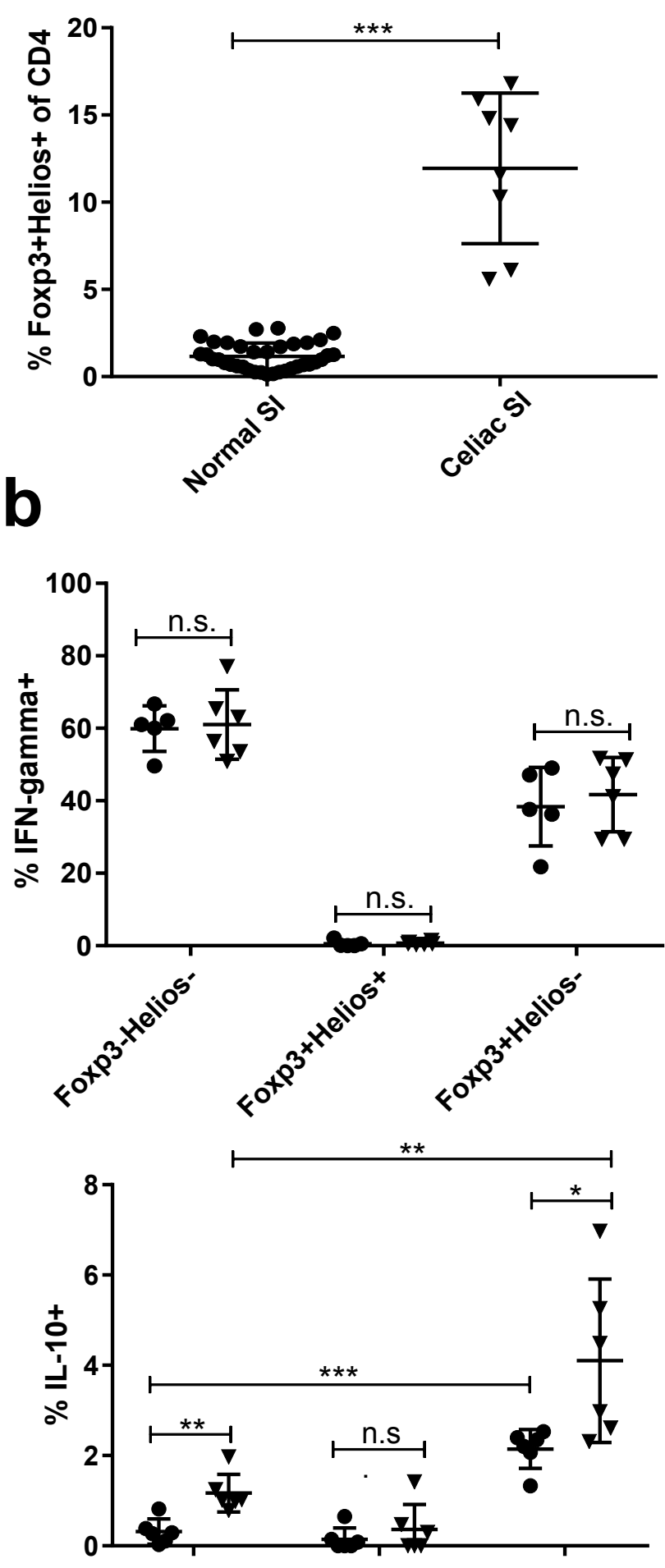
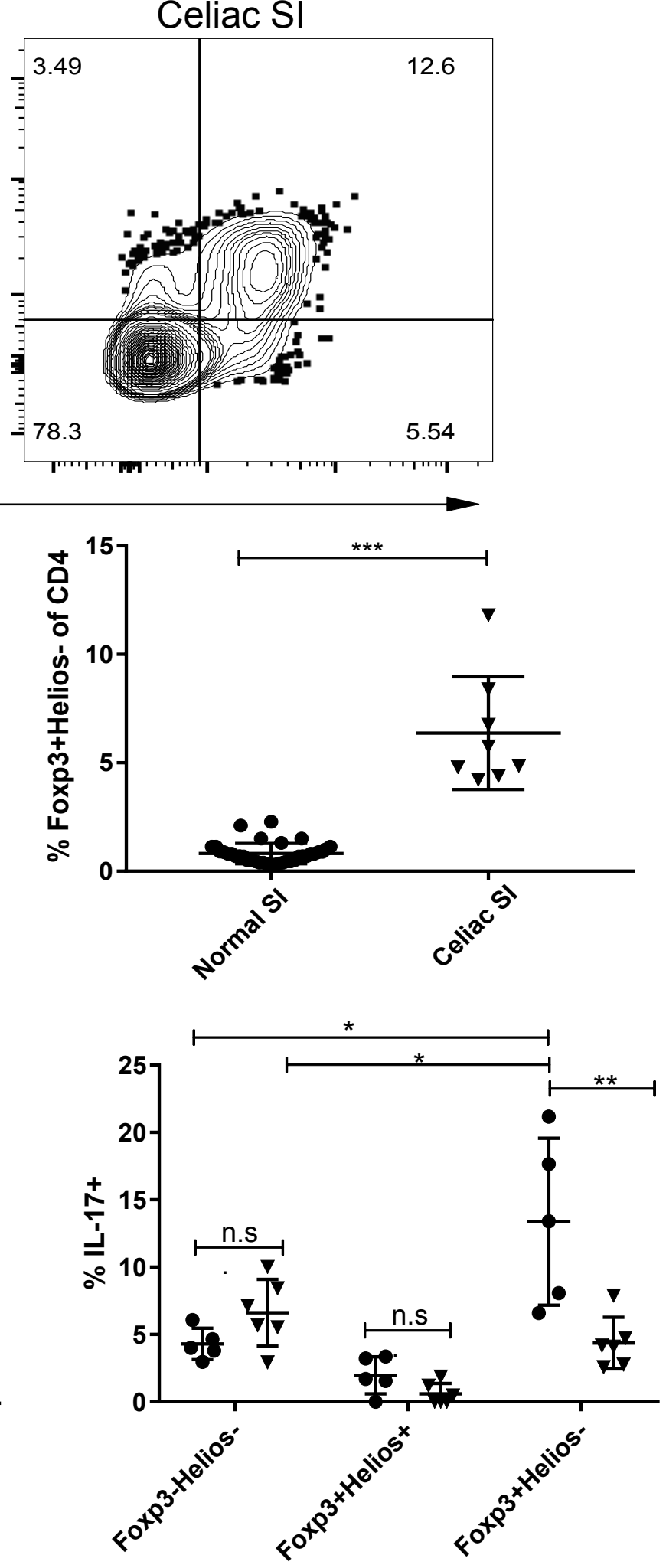

- Normal SI

$\checkmark$ Celiac SI

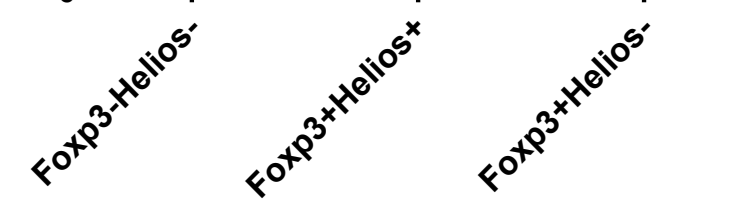

